論

\title{
プロジェクタ用光源の小型·密閉·高輝度化に関する研究
}

\author{
非会員 齋 藤 栄（シャープ株式会社）非会員 吉川 逸 郎（シャープ株式会社） \\ 非会員 京 本 忠 男 (シャープ株式会社)
}

\section{Study of Efficient-Cooling Closed Light-Source for Projectors}

Non Member Sakae Saito (Sharp Co.), Non Member Itsuro Kikkawa (Sharp Co.), and Non Member Tadao Kyomoto (Sharp Co.)

\begin{abstract}
Generally, high-pressure mercury lamps are used as the light source for projectors. This comparatively large-size and low luminosity light source is sealed by a reflector and a front glass, similar to that used as the light source for projection TVs. However, the light source used for front projectors, which needs to be small and to have high luminosity, is not sealed very well. When a luminescence pipe explodes, it is difficult to prevent a non-sealed light source from scattering mercury and shattered glass inside the projector. We studied a small, sealed, and highly luminos light source for projectors. About $130 \mathrm{~W}$ is the input limit for a sealed light source for projectors because of the problem of luminescence pipe cooling. However, we found a way to build a high luminosity, small-size, and sealed light source by developing a reflector with a four layer structure.
\end{abstract}

KEYWORDS : light source, projectors, cooling, reflector

\section{1. 緒言}

民生用プロジェクタに使用される光源装置は, 可視光反射膜を成 膜したガラスのリフレクタにショートアーク型超高圧水銀発光管を 組み込んだものが主流であり, その発光管は長寿命化の観点から再 結晶化温度以下に制御され使用されている.

リア・プロジェクション TV では, 安全面から, 光源装置外形を 大きくして密閉型光源装置を用いているが, 発光管やリフレクタの 反射膜の寿命等の観点から $130 \mathrm{~W}$ 投入が限界であり, その明るさは 低く $300 \mathrm{~cd} / \mathrm{m}^{2}$ 程度である.

しかしながら，モバイル用途やホームシアター用途のフロントプ ロジェクタでは, 光源装置が小さい事と併せ 1000 ANSIlm, $150 \mathrm{~W}$ 以上の高電力の光源装置が用いられているため, 例外無くファン等 により直接発光管を冷却するオープンエアー（密閉されていない） 構造となっている.

オープンエアーの光源装置の場合, 発光管破裂による水銀や硝子 片の飛散を防ぐため, 複雑な構造を採用しているが, それらの飛散 は完全には解消されてはおらず, 民生機器として安全性に乏しいと 言える.このため, 小型の光源装置においても密閉化が切望されて いるが，現時点ではこの世に存在していない.

ここでは，リア・プロジェクション T V 用光源装置の高輝度化と 併せ, フロントプロジェクタ用光源装置の小型密閉化技術の実現を 目指し，検討を行った.

\section{2. 検討内容}

2.1 構成

図 1 に今回開発した密閉光源の概略構造を示す.独自技術は, 高熱伝導のリフレクタ基材とその 4 層構造, そして, 空冷が無く とも発光管の温度制御を可能にする伝熱パイプ構造である.

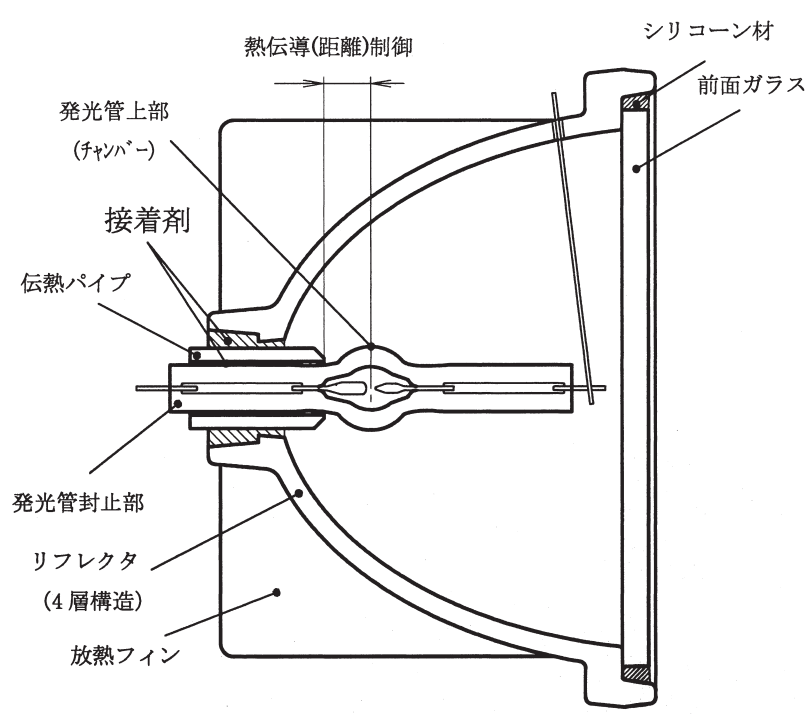

図 1 密閉型光源装置開発品

Fig.1 Prototype of closed light-source. 
密閉型プロジェクタ用光源の小型化・高輝度化を阻む要因は発光 管冷却の困難さにある.

従来の光源装置では，発光管の封体（石英）を再結晶温度以下に 制御するため, 風を発光管の上部に吹付け, その温度を, $900^{\circ} \mathrm{C}$ ら $1000^{\circ} \mathrm{C}$ 制御している.

また，リフレクタには，結晶化ガラスやホウ珪酸ガラスの耐熱性 を有する基材が用いられているが，その熱伝導率は略 $1 \mathrm{~W} / \mathrm{m} \cdot \mathrm{K}$ と低い. このため, リフレクタの発光管の発光部近傍では熱集中を 起し，可視光反射膜を破罜してしまうため，同様に風による温度制 御が必須である.

ここで，密閉化を検討するに当たり，発光管のエネルギーバラン スの解析を行なった．当社実測值を図2に示す.

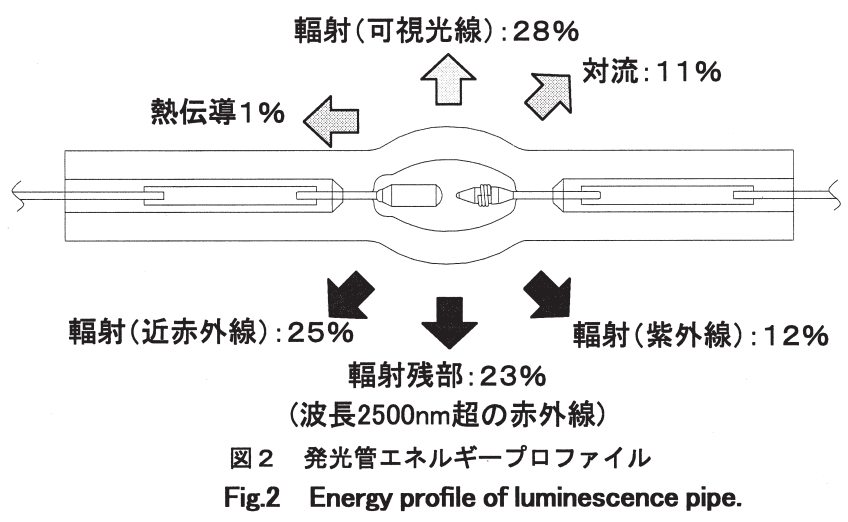

発光管の封体は, 熱伝導率の低い石英であるため, 発光管の発光 部周囲の熱は封止部に殆ど伝わらない，紫外線・赤外線は，反射膜 を可視光線反射膜, 所謂コールドミラーとする事で, 反射膜, ガラ スリフレクタ基材を透過し，放熱される．残りの輻射残部・対流伝 達成分によるリフレクタの局所的な温度上昇と, これによる発光管 の温度上昇は強制空冷で効率良く光源装置外部に放熱する事が可能 であったが, 密閉構造とする事で内部に停滞する事となり, リフレ クタ内部温度が上昇するに連れて, 発光管の温度も上昇する.
そこで，輻射残部によるリフレクタ局部の温度集中回避と，発 光管の熱伝導経路の改善を目的として, リフレクタ基材に熱伝導 率の高いアルミニウム（150 W/m・K以上）を採用した.

リフレクタ基材にアルミニウムを採用した事で，発光管の熱は リフレクタ基材に伝導し全体に拡散され, その温度は均一になる. そして, 発光管の熱放射量とリフレクタ基材の放熱表面積を最適 化設計する事でリフレクタ基材の温度制御と共に，光源装置の熱 を外部に放熱する事が可能である．また，成型の観点からも，ダ イキャスト工法が可能であるため, 反射面精度の向上や, 放熱フ インを一体形成する事が可能である等の利点が生じる.

しかしながら, 上記の利点が得られた半面, 以下の問題が発生 した.

従来では, 可視光線反射膜・ガラスリフレクタ基材を透過して いた紫外線・赤外線がアルミニウム面で（拡散）反射されてしま い, UV／I Rカットフィルタを形成した前面ガラスが配置され ているため外部に出射できず, 光源装置内部に留まるため, 発光 管及び，リフレクタの温度が上昇した。 また，アルミニウムのリ フレクタ基材と可視光反射膜（蒸着）の相性が悪く, 点灯開始後, 早い段階でクラック, 剥離が発生した。このため, 上記問題を解 決すべく, 独自の 4 層構造冷却システムを開発した。

\subsection{4 層構造冷却システム}

図 3 に 4 層構造のリフレクタを示す. 先ず，発光管から出射し た光線の内, 可視光線は, 可視光線反射膜にて反射され, 光源装 置外部の所望の集光点に到達する. 紫外線 - 赤外線は, 可視光線 反射膜, 緩衝 - 平坦化膜を透過し, 赤外線, 紫外線吸収膜に到達 し, 熱に変換される.この熱は, 高熱伝導基材に伝導し, 光源装 置の外部に放熱するシステムである.

緩衝・平坦化膜に関しては, 高熱伝導基材（アルミニウム）と 可視光線反射膜 $\left(\mathrm{TiO}_{2} / \mathrm{SiO}_{2}\right)$ の 1 析異なる熱膨張率を埋め, 可視光線反射膜のクラック・剥離を防止する機能と, 反射面の精 度・鏡面性を向上させる機能を有する。

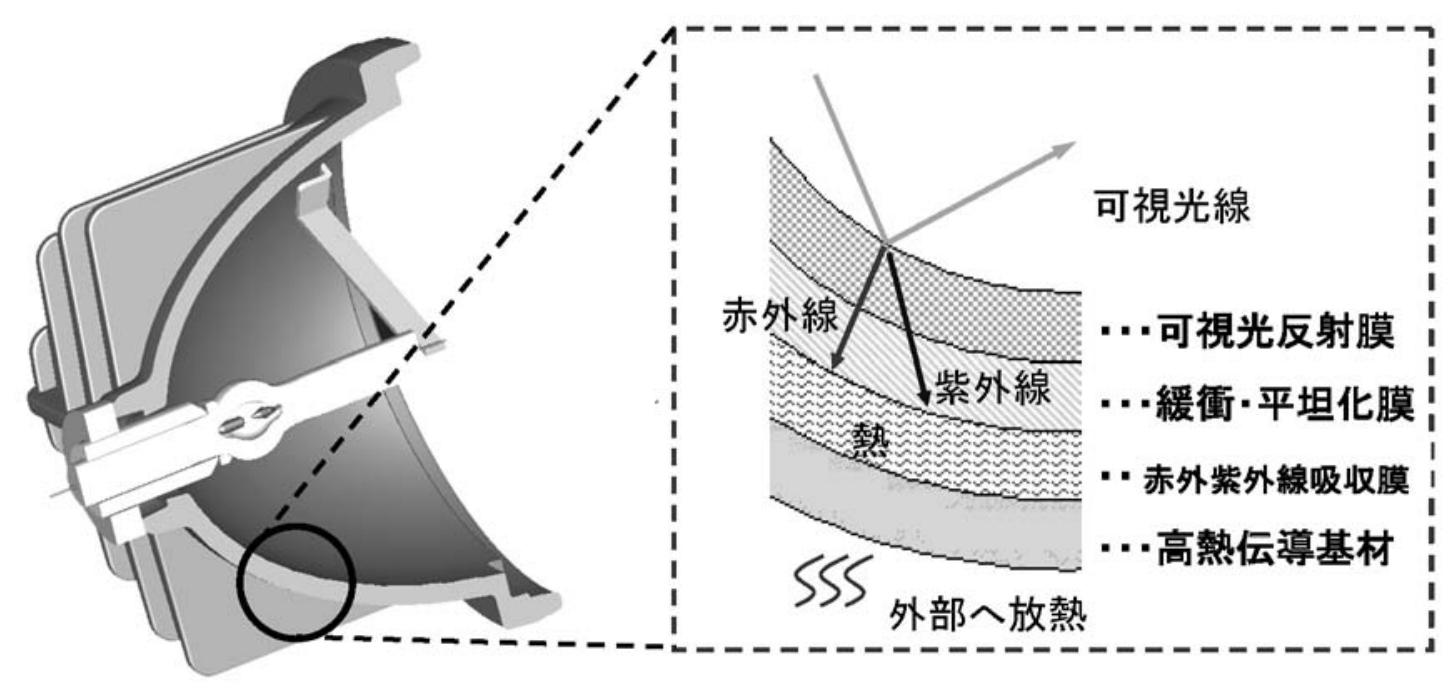

図 34 層構造 冷却システム

Fig.3 Four-layer cooling system. 
以下に 4 層構造の各層の詳細を記載する.

- 高熱伝導基材 : アルミニウム, 成型材料名 D M S -1 , 熱伝導率 $210 \mathrm{~W} / \mathrm{m} \cdot \mathrm{K}$ を主体に使用した.

ここで, 適正条件としては, 本基材の表面に陽極酸化処理を施し, 赤外線, 紫外線吸収膜を形成させるため, 純アルミニウムが好ま しい.

- 赤外線，紫外線吸収膜：陽極酸化膜 $3 \mu \mathrm{m}$, 耐熱温度 $350{ }^{\circ} \mathrm{C}$, 放射率 0.95 （@200 $\mathrm{C}$ ）を採用. 図 4 に開発品の赤外線，紫外線

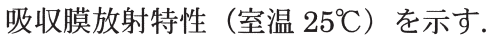

（当社実測值データ）

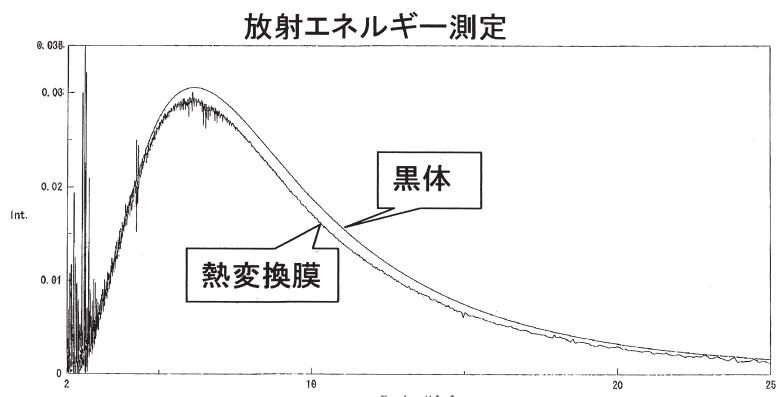

図 4 赤外線, 紫外線吸收膜の放射エネルギー測定結果

Fig.4 Emission energy of UV and IR absorbing coat.

・緩衝平坦化膜 : シリコーン, 耐熱温度 280 度, 耐紫外線に優れる. この他，ポリイミド系の評価を行ったが，耐熱性は $400^{\circ} \mathrm{C}$ と適し ているが, 耐紫外線にそしい, もしくは, 各層との相性が悪いた め, 点灯連続試験中期に, 反射膜の剥離が発生した.

図 5 には, 緩衝平坦化膜の透過特性を示した。評価したポリイミ ドでは，紫外線が透過せず，吸収している.

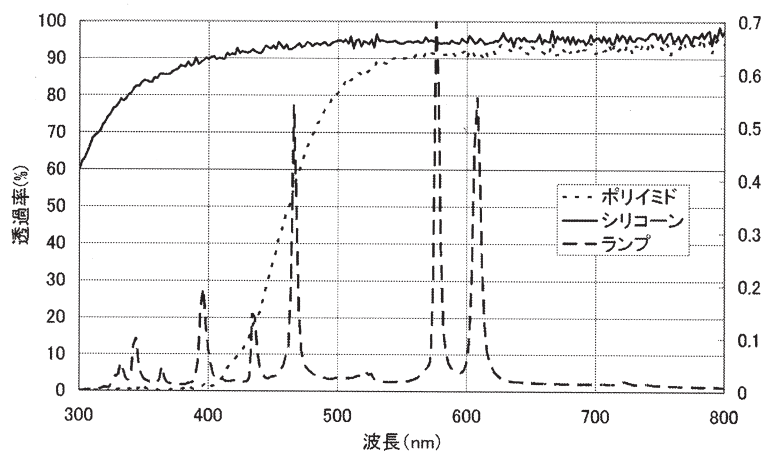

図 5 紫外線透過率測定結果

Fig.5 UV transmittance of buffer coat.

- 可視光線反射膜 : $\mathrm{TiO}_{2} / \mathrm{SiO}_{2}$ その他，一般的な誘電体多層膜の 採用が可能. 図 6 に光源装置から出射した光線の分光特性を示す.

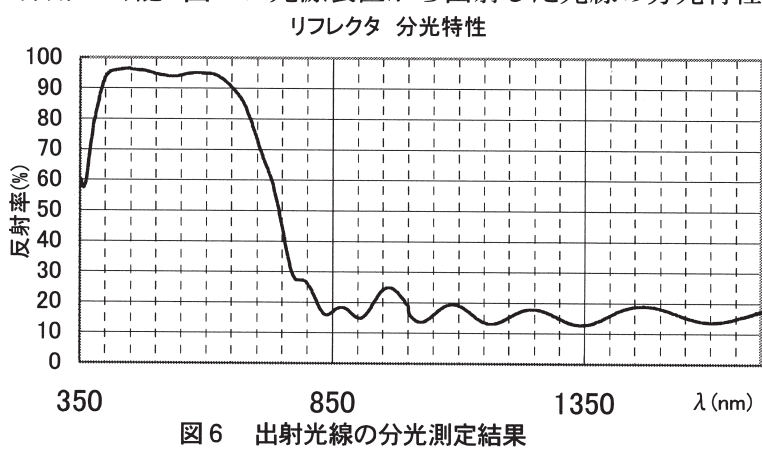

Fig.6 Spectral distribution of reflectors.

\section{3 発光管冷却構造}

従来の光源装置において, 発光管とリフレクタはアルミナ・シ リカ材の熱硬化型接着剤で固定されている事が一般的である.こ の際，発光管の熱源の内， $1 \%$ の熱が，発光管の封体（石英）と 電極を伝導し, 光源装置外部に放熱する.

光源装置の密閉構造を実現するに当たり, 発光管の温度制御を 行うために, この発光管とリフレクタ間の熱伝導経路を改善, 増 大する検討をした結果, 発光管の封止部外周へ新規に熱伝導パイ プを配置した. 本構造を図 7 に示す.

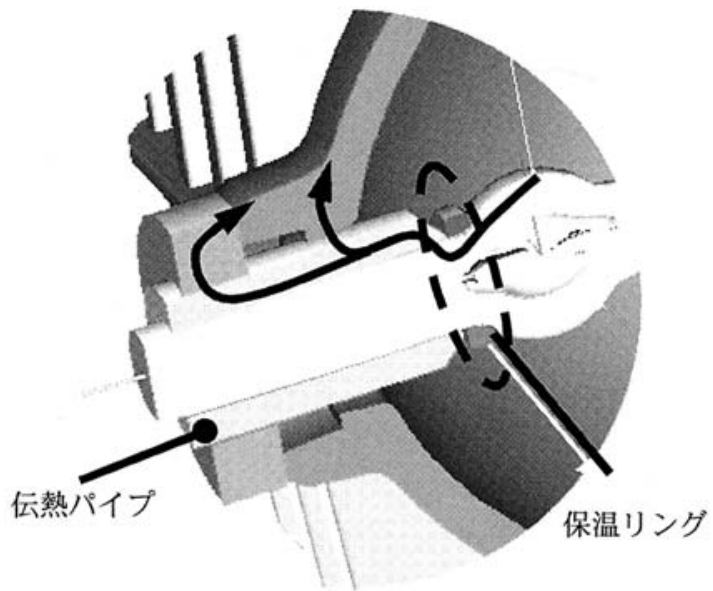

図 7 伝熱パイプ構造

Fig.7 Structure of heat transfer pipe.

発光管の発光部近傍から熱伝導のバイパス経路を設け, 熱伝導 率 $150 \mathrm{~W} / \mathrm{m} \cdot \mathrm{K}$ 以上のアルミ（合金）の伝熱パイプを設けた. 先にも述べたが, アルミニウム基材に到達した熱は, 基材の高い 熱伝導性で放熱フィンを含む基材全体へ効率良く拡散し, その放 熱面積を広くする事で, より効率の良い外部空気の放熱が可能と なった.

また, 発光管の封体形状によっては, 図 7 の点線で囲んだ発光 管の発光部端（ネック部）が冷えすぎる結果となり, 不完全なハ ロゲンサイクルのため, 黒化の進行が顕著に観察された。このた め, 耐熱温度 $1000^{\circ} \mathrm{C}$ クスの材料を用いて, ネック部を保温する 構造を採り, 最適点灯温度制御と信頼性確保が可能となった.

\section{3. 成果とアプリケーション}

・リア・プロジェクションT V（図 8）

55 型リアプロジェンクション $\mathrm{T} V$ 試作機において, 従来の 120 $\mathrm{W}$ 密閉型光源装置, 明るさ $350 \mathrm{~cd} / \mathrm{m}^{2}$ に, 今回開発した $210 \mathrm{~W}$ 密閉型光源装置を組み込んだところ, $600 \mathrm{~cd} / \mathrm{m}^{2}$ と従来比 1.7 倍 の高輝度を実現した. 冷却に関しても, リフレクタの外側に, 従 来以下の風量を流し, セットより排出する事で, 静穏化に寄与で きた.

・フロント プロジェクタ（図 9）

シアター機 $200 \mathrm{~W}$ 既製品装置と汎用設計した今回の開発品を 同電力で組み込んだところ, 反射面精度の向上により, $10 \%$ 効率 の良いスクリーン光束結果, 1700 ANSIlm が得られた. フロント プロジェクタへの密閉型光源装置の搭載は初であり，ガラス片や 水銀の飛散が回避可能である. 

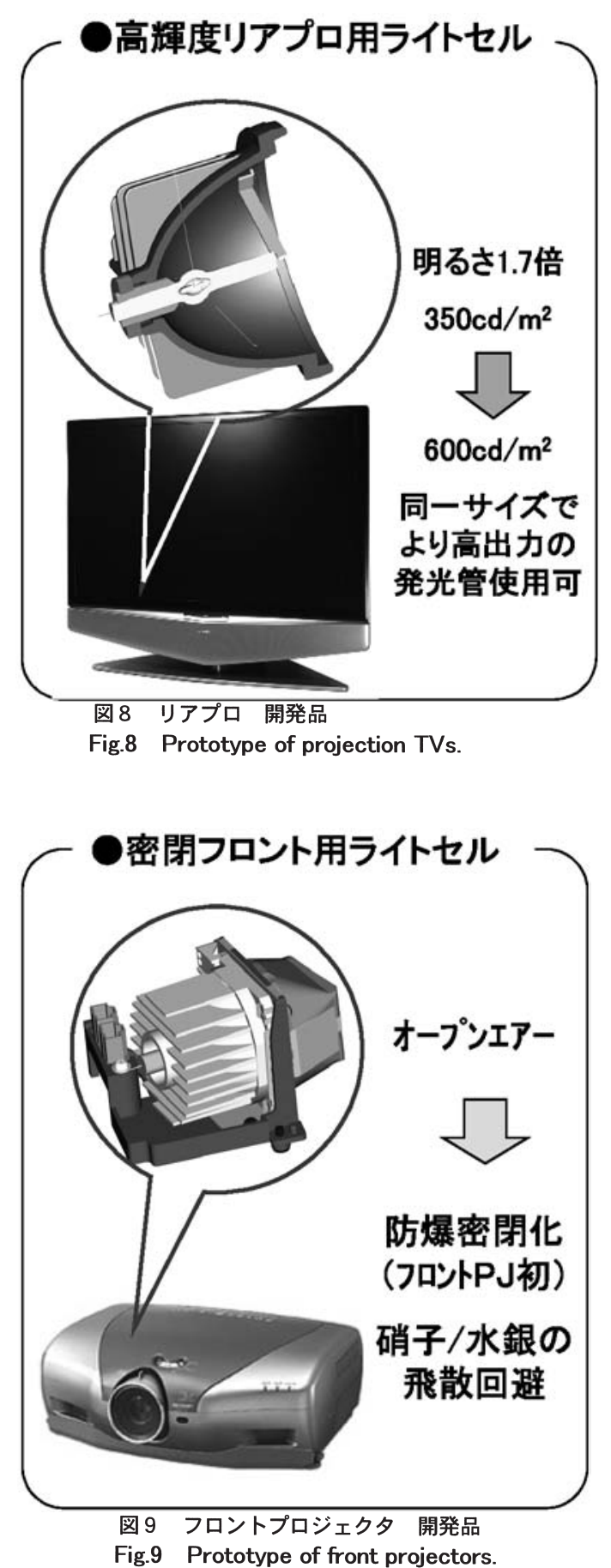

\section{4. 結言}

従来，超高圧水銀発光管を用いたプロジェク夕用光源装置は，密 閉構造では発光管の最適点灯温度の制約で $130 \mathrm{~W}$ 程度の投入電力 が限界であった。しかし，今回の検討結果より発光管からリフレク タへの熱伝導冷却構造と, 発光管から放出される赤外線をリフレク 夕で吸収する事により，2 $10 \mathrm{~W}$ 投入が可能となり高輝度化を実現 できた.

これら 4 層構造リフレクタや熱伝導パイプ構造の検討結果を元 に，当社では，超小型光源装置の開発に着手し，A 6 サイズの超小 型プロジェクタの試作に成功した.ここでは概略紹介を行なう.
超小型光源装置には，先に述べた冷却システムに加えて独自の 超小型・短焦点光学設計を導入し, $165 \mathrm{~W}$ 超小型密閉光源装置 が実現できた. 図 10 に試作した超小型光源装置を示した. 今回 の超小型光源装置に関しては, 高さ $30 \mathrm{~mm}$ であるが，同電力で 26 $\mathrm{mm}$ が可能である.

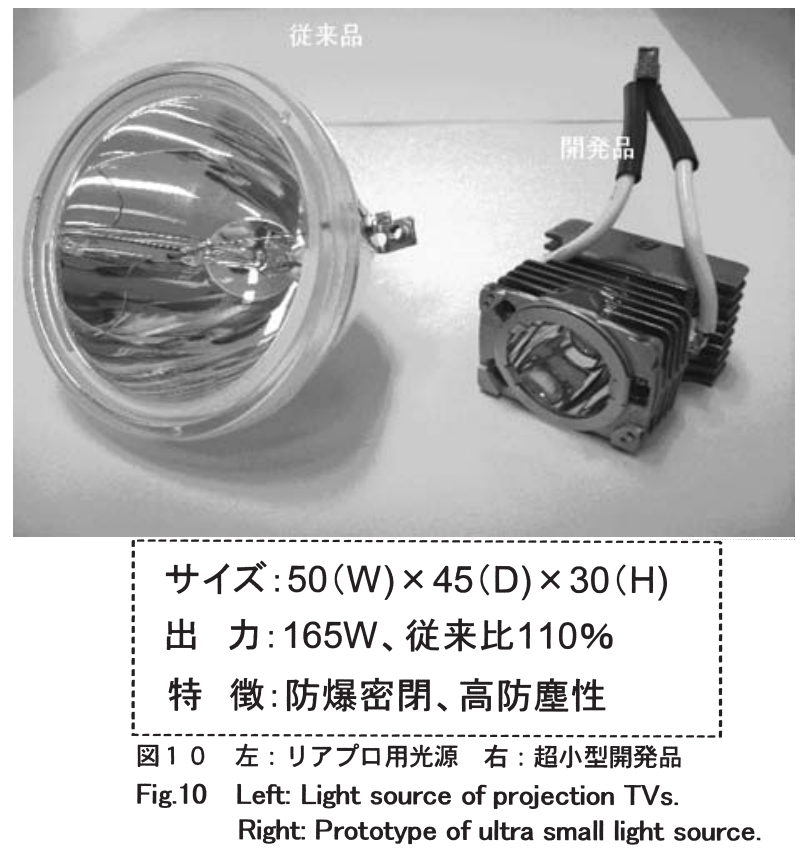

次に, 図 11 にA 6 サイズプロジェクタを示した.

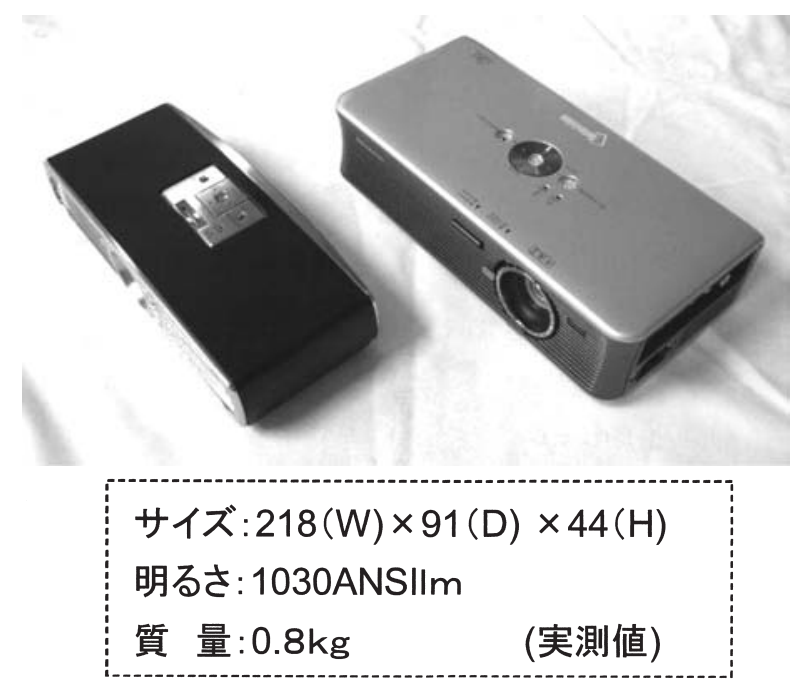

図 11 左: A6 試作品 右: 当社プロジェク夕製品

Fig.11 Left: Prototype of "A6" projector.

Right: Production of front projectors.

現在, 上記 A 6 サイズプロジェクタの更に半分のプロジェクタの 開発を行なっている.

\section{謝辞}

本研究を進めるにあたり, 協業いただきました各社の方々に深く お礼申し上げます。

（受付日 2006 年 11 月 13 日/採録日 2007 年 5 月 11 日） 


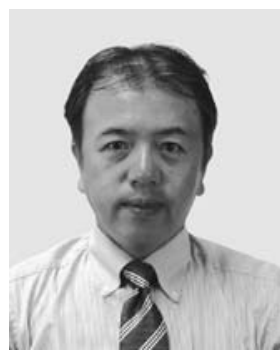

齋藤 栄（非会員）

シャープ株式会社

干261-8520 千葉県千葉市美浜区中瀬1-9-2 1957年生まれ. 1980年茨城大学工学部精密工 学科卒. 同年 4 月シャープ株式会社入社. 現 在技術本部, 先端映像技術研究所, 第 2 研究 室にて, 次世代映像システム要素技術開発に 従事.

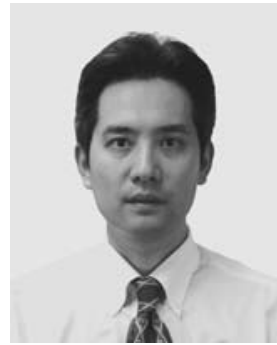

吉川 逸郎（非会員）

シャープ株式会社

干261-8520 千葉県千葉市美浜区中瀬 1-9-2 1966 年生まれ. 1990 年東京理科大学理工学 部物理学科卒. 同年 4 月シャープ株式会社入 社. 現在技術本部, 先端映像技術研究所, 第 2 研究室にて, 次世代映像システム要素技術

開発に従事.

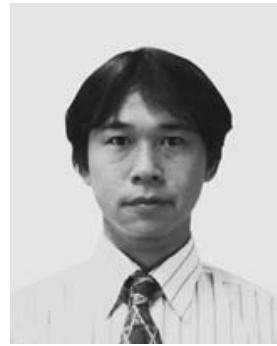

京本 忠男（非会員）

シャープ株式会社

于261-8520 千葉県千葉市美浜区中瀬1-9-2 1969 年生まれ. 1992 年日本大学理工学部電 子工学科卒. 同年 4 月シャープ株式会社入 社. 現在技術本部, 先端映像技術研究所, 第 2 研究室にて, 次世代表示システム研究開発

に従事. 